\title{
OPTIMALISASI LAHAN PEKARANGAN DI DESA PANDEYAN, GROGOL, SUKOHARJO
}

\author{
Joko Sutrisno, Eddy Triharyanto \\ Pusat Pengembangan Kewirausahaan Lembaga Penelitian dan Pengabdian Kepada Masyarakat \\ Universitas Sebelas Maret, Jl. Ir. Sutami No.36A Kentingan, Jebres, Surakarata, 57126, \\ Indonesia \\ Email: jokosutrisno@staff.uns.ac.id
}

\begin{abstract}
ABSTRAK
Kecamatan Grogol merupakan salah satu Kecamatan di Sukoharjo Jawa Tengah yang mengalami alih fungsi lahan sawah menjadi permukiman, perusahaan dan penggunaan lainnya. Salah satu wilayah perumahan yang ada di Kecamatan Grogol adalah perumahan Pandeyan. Luas pekarangan yang dapat dijadikan area tanam hanya sedikit sedangkan harga bahan pangan hasil pertanian semakin mahal. Pengoptimalan lahan pekarangan yang sempit sangat diperlukan dalam hal ini. Hidroponik dan vertikultur merupakan metode tanam tanpa tanah dan lahan pekarangan sempit. Selama ini Ibu-ibu rumah tangga kecamatan Grogol belum memaksimalkan pemanfaatan lahan pekarangan rumahnya karena keterbatasan pengetahuan tentang metode bercocok tanam. Oleh karena itu diperlukan pendampingan untuk mengenalkan teknik-teknik pemanfaatan lahan pekarangan sempit di area perumahan, khususnya di Perumahan Pandeyan kepada ibu-ibu kelompok PKK. Hal ini bertujuan untuk meningkatkan produktivitas area pekarangan yang ada. Metode yang digunakan untuk membantu mengatasi permasalahan di atas antara lain: pelatihan manajemen usaha, pelatihan dan pemberian sebagian bantuan dukungan teknologi tepat guna, dan pendampingan.
\end{abstract}

Kata kunci: hidroponik, vertikultur, produktivitas pekarangan, pandeyan

\begin{abstract}
Grogol sub-district is one of the subdistricts in Sukoharjo, Central Java, which has transformed rice fields into settlements, companies and other uses. One of the existing residential areas in Grogol District is Pandeyan. The area of the yard that can be used for planting area only slightly while the price of food crops was more expensive. The narrow garden optimization is necessary in this regard. Hydroponics and vertikulture is a method of planting without soil and small garden yard. So far, Grogol sub-district housewives have not maximized the utilization of their home yards due to the limited knowledge of farming methods. Therefore, assistance is needed to introduce narrow gardening techniques in residential areas, especially in Pandeyan to PKK group mothers. It aims to increase the productivity of the existing yard area. Methods used to
\end{abstract}


help overcome the above problems include: business management training, training and partial support of appropriate technology support, and assistance.

Key words: hydroponics, verticultur, yard productivity, pandeyan

\section{PENDAHULUAN}

Pertumbuhan penduduk yang tinggi di Indonesia yang biasa disebut dengan bonus demografi secara nyata berpengaruh terhadap alih fungsi lahan. Termasuk di Kabupaten Sukoharjo. Dari data BPS Sukoharjo (2013), diketahui bahwa alih fungsi lahan sawah menjadi permukiman, perusahaan dan penggunaan lainnya terjadi paling tinggi di Kecamatan Grogol Sukoharjo. Berdasarkan data BPS Sukoharjo pada Tahun 2008 sektor pekarangan/bangunan menempat area seluas $16.087 \mathrm{Ha}$, sedangkan Tahun 2013 pada sektor pekarangan/bangunan berkembang menjadi seluas 16.464 Ha. Hal ini menunjukan bahwa Kabupaten Sukoharjo mengalami perubahan yang cukup tinggi, terutama kebutuhan akan permukiman dan penggunaan lainnya yang berkaitan dengan perkembangan dan pembangunan. Tingginya pertumbuhan perumahan di Kecamatan Grogol ini salah satunya disebabkan karena lokasinya yang strategis yang berbatasan langsung dengan kota Solo.

Salah satu wilayah perumahan yang ada di Kecamatan Grogol adalah perumahan Pandeyan. Di wilayah ini, seperti halnya perumahan lainnya, luas pekarangan yang dapat dijadikan area tanam hanya sedikit. Bahkan ada yang tidak memiliki lahan pekarangan. Padahal tidak semua penghuni Perumahan termasuk ke dalam golongan mampu. Berdasarkan data dari Badan Pusat Statistik kabupaten Sukoharjo jumlah penduduk miskin sebesar 79,94 ribu jiwa.

(https://sukoharjokab.bps.go.id/inde x.php/publikasi)

Harga bahan pangan hasil pertanian yang semakin fluktuatif pada saat ini menyebabkan pengeluaran untuk kebutuhan pangan menjadi tidak stabil. Meski begitu, bagi sebagian besar orang yang tinggal di perumahan tetap harus membelinya mengingat tidak tersedianya lahan yang dapat mereka gunakan untuk bertanam.

Lahan pekarangan di area perumahan pada dasarnya bisa digunakan untuk bercocok tanam dengan menggunakan metodemetode tertentu seperti hidroponik yang merupakan metode bercocok tanam tanpa menggunakan tanah begitupula dengan vertikultur yang menanam tanaman dengan system vertical ke atas sehingga tidak membutuhkan banyak lahan. Akan tetapi belum banyak masyarakat, khususnya ibu rumah tangga yang mengetahui metode ini.

Oleh karena itu diperlukan pendampingan untuk mengenalkan teknik-teknik pemanfaatan lahan pekarangan sempit di area perumahan, khususnya di Perumahan Pandeyan kepada ibu-ibu rumah tangga yang tergabung dengan kelompok PKK. Hal ini bertujuan untuk meningkatkan produktivitas area pekarangan yang ada. 
Kegiatan ini melibatkan tenant PPKwu yang merupakan pemilik usaha Bakoel Sayur. Tenant ini adalah supplier bahan-bahan pertanian dengan system hidoponik dan vertikultur. Melalui kegiatan ini diharapkan terjadi simbiosis mutualisme antara tenant Bakoel Sayur dengan ibu-ibu PKK dimana ibu-ibu PKK di Perumahan Pandeyan dapat menjadi konsumen tenant.

\section{METODE}

Metode yang digunakan untuk membantu mengatasi persoalanpersolan yang telah disepakati di atas adalah melalui pelatihan manajemen usaha, pelatihan dan pemberian sebagian bantuan dukungan teknologi tepat guna, dan pendampingan:

\section{A. Metode Kegiatan}

1. Pelatihan in-class dan pelatihan out-class (praktek hidroponik vertikultur). Pelatihan dilakukan untuk meningkatkan pemahaman para peserta dalam pengoptimalan suatu lahan pekarangan, teknik budidaya tanaman maupun motivasi berwirausaha serta upaya meningkatkan keterampilan teknis pengoptimalan lahan pekarangan melalui budidaya vertikultur.

2. Peningkatan kemampuan teknologi bercocok tanam

3. Peningkatan kemampuan Ibuibu anggota PKK desa Pandeyan dalam hal pemanfaatan lahan pekarangan.

4. Evaluasi kegiatan dilakukan pada dua aspek yaitu, evaluasi proses dan evaluasi produk.
Evaluasi proses dimaksudkan untuk mengetahui keefektifan proses berlangsungnya kegiatan program.

B. Partisipasi Mitra dalam Pelaksanaan Program:

Dalam melaksanakan kegiatan ini, Ibu-Ibu PKK desa Pandeyan dan Bakoel Sayur bersedia mengikuti seluruh kegiatan yang telah ditetapkan sesuai dengan kesepakatan bersama. Hal ini dibuktikan dengan surat kesediaan berkerjasama antara PPKwu UNS dengan mitra program IbM. Selama kegiatan, kedua mitra berpartisipasi aktif melalui berbagai kegiatan yang akan ditransfer kepada mitra IbM.

\section{HASIL DAN PEMBAHASAN}

Kegiatan pengabdian masyarakat ini bertujuan untuk mengoptimalan lahan pekarangan, meningkatkan pengetahuan ibu-ibu PKK terhadap sistem budidaya tanam, meningkatkan kesejahteraan desa Pandeyan, meningkatkan motivasi berwirausaha Ibu-ibu PKK desa Pandeyan serta memperluas pangsa pasar Bakoel Sayur. Pada tanggal 10 Juli 2017 dilakukan tapat koordinasi awal yang dihadiri oleh tim pengabdi di kantor PPKwu LPPM UNS. Hasil rapat yaitu tersusunnya teknis pelaksanaan pengabdian di desa Pandeyan, Grogol, Sukoharjo. Dengan menganalisa informasi yang ada, selanjutnya ditentukan tindakantindakan yang akan dilakukan.

Kegiatan pelatihan in-class dilakukan pada tanggal 16 Juli 2017 salah satu rumah anggota PKK Desa 
Pandeyan, Grogol, Sukoharjo. Kegiatan ini diikuti oleh 35 orang anggota PKK Desa Pandeyan, Grogol, Sukoharjo. Materi yang disampaikan dalam pelatihan ini mengenai manajemen tanam, teknik bercocok tanam hidroponik vertikultur, dan instalasi tanaman hidroponik vertikultur.

Kegiatan pelatihan out-class dilaksanakan pada tanggal 19 Agustus 2017 di salah satu rumah anggota PKK desa Pandeyan, Grogol, Sukoharjo. Narasumber pelatihan outclass ini adalah mitra 2. Pada kegiatan ini, materi yang disampaikan antara lain adalah penyemaian bibit yang akan di tanam. Bibit yang disemai antara lain adalah bayam merah, pakcoy, kangkung, selada dan sawi sendok. Selain penyemaian bibit, pelatihan ini juga meberikan materi tentang formulasi nutrisi tanam. Pada kegiatan ini juga, tim pengabdi menyerahkan TTG berupa 40 stater kit Wick System dan Instalasi Hidroponik kepada anggota PKK desa Pandeyan, Grogol, Sukoharjo.

Kegiatan pendampingan mitra dilakukan pada tanggal 20 September 2017 di salah satu rumah anggota PKK desa Pandeyan, Grogol, Sukoharjo. Kegiatan dilaksanakan pada pukul 16.00 WIB. Kegiatan pendampingan yang diberikan antara lain antara lain dalam bentuk pendampingan ketika penanaman bibit semai ke media tanam, ketika panen tanaman hasil hidroponik yang benar, dan cara perawatan tanaman secara kontinyu. Pada kesempatan ini, tim pengabdi menyerahkan Instalasi Rumah Hidroponik kepada Kelompok
PKK desa Pandeyan, Grogol, Sukoharjo.

Kegiatan monitoring dan evaluasi dilakukan untuk memastikan kegiatan berlangsung sesuai dengan yang direncanakan. Evaluasi kegiatan dilakukan pada dua aspek yaitu, evaluasi proses dan evaluasi pencapaian target. Evaluasi proses dimaksudkan untuk mengetahui efektivitas berlangsungnya kegiatan sedangkan evaluasi pencapaian target dimaksudkan untuk mengetahui tingkat keberhasilan program sesuai dengan proses yang dilaksanakan.

Berdasarkan hasil pengabdian, masih perlu pendampingan dalam hal inovasi pemanfaatan barang bekas untuk media tanam hidroponik agar lebih enak dipandang. Pengabdian ini dilakukan untuk mengenalkan teknikteknik pemanfaatan lahan pekarangan sempit di area perumahan, khususnya di Perumahan Pandeyan kepada ibuibu rumah tangga yang tergabung dengan kelompok PKK sehingga dapat meningkatkan produktivitas area pekarangan yang ada.

\section{KESIMPULAN}

Perumahan Pandeyan merupakan salah satu perumahan yang ada di Kecamatan Grogol Sukoharjo. Luas pekarangan perumahan ini yang dapat dijadikan area tanam hanya sedikit. Bahkan ada yang tidak memiliki lahan pekarangan. Selain itu harga bahan pangan hasil pertanian yang semakin mahal menyebabkan pengeluaran untuk kebutuhan pangan menjadi tidak stabil. Meski begitu, bagi sebagian besar orang yang tinggal di perumahan tetap harus 
membelinya mengingat tidak tersedianya lahan yang dapat mereka gunakan untuk bertanam. Pengabdian ini dilakukan untuk mengenalkan teknik-teknik pemanfaatan lahan pekarangan sempit di area perumahan, khususnya di Perumahan Pandeyan kepada ibu-ibu rumah tangga yang tergabung dengan kelompok PKK dengan menggunakan metode tanam hidroponik dan vertikultur. Hal ini bertujuan untuk meningkatkan produktivitas area pekarangan yang ada. Tim IbM memberikan bantuan teknologi (rangkaian hidroponik vertikultur), pelatihan pengoptimalan lahan pekarangan menggunakan inovasi budidaya hidroponik vertikultur, pelatihan instalasi hidroponik vertikultur tanaman pangan, serta pendampingan (monitoring, advokasi, edukasi, informasi) berkelanjutan pengoptimalan lahan pekarangan oleh mitra 1 dan mitra 2. Dalam menjalankan kegiatan utama, tim pengabdi bekerjasama dengan tenant PPKwu yang merupakan pemilik usaha "Bakoel Sayur" (Mitra II). Melalui pengabdian ini, terjadi simbiosis mutualisme antara tenant Bakoel Sayur dengan ibu-ibu PKK dimana ibu-ibu PKK di Perumahan Pandeyan dapat menjadi konsumen tenant.

\section{DAFTAR PUSTAKA}

Agoes H. 2000. Mengenal Hidroponik Bercocok Tanam tanpa Tanah. Agromedia Pustaka:Jakarta.

Hartus T. 2007. Berkebun Hidroponik secara Murah. Penebar Swadaya: Jakarta.

Rukmana R. 2005. Bertanam Sayuran di Pekarangan. Kanisius, Yogyakarta.

Sastro Y dan Indarti P L. 2011. Vertikultur andalan pertanian di perkotaan. BPTP Sumatera Selatan Edisi Khusus Penas XIII.

Sugianto Y. 2013. Manfaat Pupuk Pada Tanaman. (online) http://yusufsugianto88.blogspo t.com. Diakses pada 24 Mei 2015

Suhardiyanto H. 2009. Teknologi Vertikultur untuk Budidaya Tanaman. Departemen Teknik Pertanian. Bogor, Institut Pertanian Bogor. 